\title{
An iron budget during the natural iron fertilisation experiment KEOPS (Kerguelen Islands, Southern Ocean)
}

\author{
F. Chever ${ }^{1,2}$, G. Sarthou ${ }^{1,2}$, E. Bucciarelli ${ }^{1,2}$, S. Blain $^{3,4}$, and A. R. Bowie ${ }^{5}$ \\ ${ }^{1}$ Université Européenne de Bretagne, 35000 Rennes, France \\ ${ }^{2}$ Université de Brest, CNRS, IRD, UMR 6539 LEMAR, IUEM; Technopôle Brest Iroise, Place Nicolas Corpernic, \\ 29280 Plouzané, France \\ ${ }^{3}$ Laboratoire Océanographie Biologique de Banyuls sur Mer, Université Pierre et Marie Curie, Paris 06, quai Fontaulé, \\ 66650 Banyuls sur Mer, France \\ ${ }^{4}$ Laboratoire Océanographie Biologique de Banyuls sur Mer, CNRS, quai Fontaulé, 66650 Banyuls sur Mer, France \\ ${ }^{5}$ Antarctic Climate and Ecosystems Cooperative Research Centre (ACE CRC), University of Tasmania, Hobart, Australia
}

Received: 29 May 2009 - Published in Biogeosciences Discuss.: 10 July 2009

Revised: 5 January 2010 - Accepted: 12 January 2010 - Published: 2 February 2010

\begin{abstract}
Total dissolvable iron (TDFe) was measured in the water column above and in the surrounding of the Kerguelen Plateau (Indian sector of the Southern Ocean) during the KErguelen Ocean Plateau compared Study (KEOPS) cruise. TDFe concentrations ranged from 0.90 to $65.6 \mathrm{nmol} \mathrm{L}^{-1}$ above the plateau and from 0.34 to $2.23 \mathrm{nmol} \mathrm{L}^{-1}$ offshore of the plateau. Station C1 located south of the plateau, near Heard Island, exhibited very high values (329$\left.770 \mathrm{nmol} \mathrm{L}^{-1}\right)$. Apparent particulate iron $\left(\mathrm{Fe}_{\text {app }}\right)$, calculated as the difference between the TDFe and the dissolved iron measured on board (DFe) represented $95 \pm 5 \%$ of the TDFe above the plateau, suggesting that particles and refractory colloids largely dominated the iron pool. This paper presents a budget of $\mathrm{DFe}$ and $\mathrm{Fe}_{\text {app }}$ above the plateau. Lateral advection of water that had been in contact with the continental shelf of Heard Island seems to be the predominant source of $\mathrm{Fe}_{\text {app }}$ and DFe above the plateau, with a supply of $9.7 \pm 3.6 \times 10^{6}$ and $8.3 \pm 11.6 \times 10^{3} \mathrm{~mol} \mathrm{~d}^{-1}$, respectively. The residence times of 1.7 and 48 days estimated for $\mathrm{Fe}_{\text {app }}$ and $\mathrm{DFe}$ respectively, indicate a rapid turnover in the surface water. A comparison between $\mathrm{Fe}_{\text {app }}$ and total particulate iron (TPFe) suggests that the total dissolved fraction is mainly constituted of small refractory colloids. This fraction does not seem to be a potential source of iron to the phytoplankton in our study. Finally, when taking into account the lateral supply of dissolved iron, the seasonal carbon sequestration efficiency was estimated at $154000 \mathrm{~mol} \mathrm{C}(\mathrm{mol} \mathrm{Fe})^{-1}$,
\end{abstract}

Correspondence to: G. Sarthou (geraldine.sarthou@univ-brest.fr) which is 4-fold lower than the previously estimated value in this area but still 18 -fold higher than the one estimated during the other study of a natural iron fertilisation experiment, CROZEX.

\section{Introduction}

Iron $(\mathrm{Fe})$ is essential for the growth of marine phytoplankton (Sunda, 1989), and plays an important role in biochemical reactions such as photosynthesis and nitrate reduction (Rueter and Ades, 1987; Kutska et al., 2002). Artificial and natural Fe fertilisations in High Nutrient Low Chlorophyll (HNLC) regions of the World's oceans have shown that iron inputs enhance phytoplankton growth and partly control the major biogeochemical cycles of elements important for Earth's climate (Boyd et al., 2000; Coale et al., 2004; Blain et al., 2007; Pollard et al., 2009). However, many uncertainties exist following such fertilisation experiments, for example the carbon sequestration efficiency, i.e. the amount of carbon exported to the deep ocean per unit iron added.

Moreover, the biogeochemical cycle of iron is still not well understood. This is partly due to its complex physicochemical speciation. Iron exists in different forms and the availability of these forms to phytoplankton is not well established (Bruland and Rue, 2001). The physical speciation is operationally defined as the partitioning between dissolved iron $(\mathrm{DFe},<0.2 \mu \mathrm{m})$ and particulate iron $(\mathrm{PFe},>0.2 \mu \mathrm{m})$. Although particulate fraction may be the dominant pool of total iron in the water column (de Baar and de Jong, 2001), the majority of the studies had focused on the dissolved phase

Published by Copernicus Publications on behalf of the European Geosciences Union. 
which is thought to be a proxy for the bioavailable form (Frew et al., 2006; Morel et al., 2008). Exchanges between the different physical pools of iron take place in seawater, and an understanding of the distribution of iron in those pools, as well as of the fluxes between them is needed to better constrain the iron cycle in the ocean (Frew et al., 2006). Only a few studies have shown that part of the particulate iron may be used by phytoplankton (Johnson et al., 2001; Maldonado et al., 2001). Small-particles below the defined colloidal size range (0.02-0.2 $\mu \mathrm{m}$; Wu et al., 2001), and included in the dissolved phase, have also been considered to be a possible bioavailable form of iron to phytoplankton although less available than the truly soluble iron (Wu et al., 2001).

Acidified unfiltered samples allow the determination of total dissolvable iron (TDFe). That fraction represents the sum of the dissolved iron (i.e. the labile dissolved iron which is the fraction that is released after a few days of acidification) plus the refractory colloidal iron (i.e., that fraction that dissolved after more than a few days of acidification) plus the fraction of particulate material that dissolves during extended ( $>6$ months) acid storage (iron adsorbed on lithogenic or biogenic particles, contained within biogenic particles and labile lithogenic particulate iron) (de Baar et al., 1999; Löscher et al., 1997; Bowie and Sedwick, 2004). In the literature, the set of TDFe observations is much smaller than that of DFe. Studies of TDFe can however give important information about the iron cycle, notably on the sources of iron to the ocean. Indeed, lithogenic material deposited on continental shelf sediments and atmospheric dust inputs, which are the most important $\mathrm{Fe}$ sources in the surface waters of the open ocean, have been correlated with elevated concentrations of TDFe (Jickells et al., 2005; Elrod et al., 2004; Sarthou et al., 1997; Sedwick et al., 2008; Croot et al., 2004).

During the KEOPS (Kerguelen Ocean and Plateau compared Study) cruise, a multi-tracer approach was used to identify and quantify natural iron fertilisation over the plateau. DFe $(>0.2 \mu \mathrm{m})$ was analysed on board and it represented the labile dissolved iron (i.e., soluble Fe and colloidal $\mathrm{Fe}$ dissolving after a few days of acid storage). The study of this fraction clearly demonstrated the existence of a dissolved iron-rich reservoir above the plateau below the mixed layer (Blain et al., 2007). At the date of the cruise (JanuaryFebruary 2005), DFe enrichment was partly due to inputs from the sediment above the plateau and/or to regeneration of biogenic particles. Predominant mechanisms allowing DFe transport into surface waters were shown to be diapycnal diffusive flux and winter mixing (Blain et al., 2008). However, other geochemical tracers have suggested that the dissolution of lithogenic material transported over the plateau by lateral advection might also be a source of iron to this region (Zhang et al., 2008; van Beek et al., 2008; Jacquet et al., 2008). Additionally, Park et al. (2008a) showed that the flow over the shallow platform in the eastern side of the plateau is consistently northwestward. This feature is strongly supported by depth-averaged (over the first $500 \mathrm{~m}$ depth) time- mean currents directly measured by one-year-long current meter moorings at 2 stations (located above the plateau at $50.2^{\circ} \mathrm{S} / 72.3^{\circ} \mathrm{E}$ and $49.5^{\circ} \mathrm{S} / 73.0^{\circ} \mathrm{E}$ ), as well as by repeated LADCP measurements at $\mathrm{A} 3$ and $\mathrm{C} 11$. A transport of iron from Heard Island to the plateau should thus be possible.

The present work focuses on the distribution of TDFe above the Kerguelen plateau and in the surrounding waters, and uses this parameter as an additional tracer to better constrain the Fe cycle in a naturally fertilised area. A budget of $\mathrm{DFe}$ and $\mathrm{Fe}_{\mathrm{app}}$ for the region located above the plateau is presented and the fluxes exchanged between these two pools are calculated.

\section{Material and methods}

\subsection{Study area}

During the KEOPS cruise (18 January to 13 February 2005), three transects were studied (A, B and C). Seven stations located above the Kerguelen plateau (A3, B1, B3, B5, B7, C1 and $\mathrm{C} 5$; water depth from 150 to $607 \mathrm{~m}$ ) and two stations located outside the plateau (B11, C11; water depth $>3000 \mathrm{~m}$ ) were sampled for TDFe (unfiltered samples) (Fig. 1).

The hydrology and the circulation around and above the Kerguelen Plateau have been described by Park et al. (2008a, b). Briefly the Kerguelen Plateau constitutes a barrier to the eastward flowing Antarctic Circumpolar Current (ACC). Most of the ACC is deflected north of the Kerguelen Islands but a remainder passes between the Kerguelen Islands and Antarctica. Above the plateau, the remainder of the ACC comes from the western part of the plateau (see Fig. 1). Currents travel along the western flank of the plateau, passing south and east of Heard Island, before riding up above the plateau. South of the plateau, a branch of the Fawn Trough Current (FTC) flows toward the north along the eastern flank of the plateau (near stations B11 and C11).

\subsection{Sampling and analyses}

Samples were collected with acid-cleaned 12 L Go-Flo bottles mounted on a Kevlar cable. All sampling was carried out in a clean-room container. Unfiltered samples were collected in acid-cleaned $125 \mathrm{~mL}$ high density polyethylene (HDPE) bottles and immediately acidified with ultrapure hydrochloric acid ( $\mathrm{HCl}$, Merck, $250 \mu \mathrm{L}$, final $\mathrm{pH} 1.7)$. Samples were stored at room temperature and analysed 18 months later in the shore-based laboratory (LEMAR, Brest, France), in order to release the most refractory Fe species into the dissolved form (Löscher et al., 1997; Bowie and Sedwick, 2004).

TDFe analyses were performed by flow injection analysis (FIA) with on line preconcentration and chemiluminescence detection (Obata et al., 1993; Sarthou et al., 2003), identical to the method used for DFe (Blain et al., 2008). The mean blank was equal to $0.07 \pm 0.07 \mathrm{nmol} \mathrm{L}^{-1}(n=9)$ and the detection limit equal to three times the standard deviation of the 


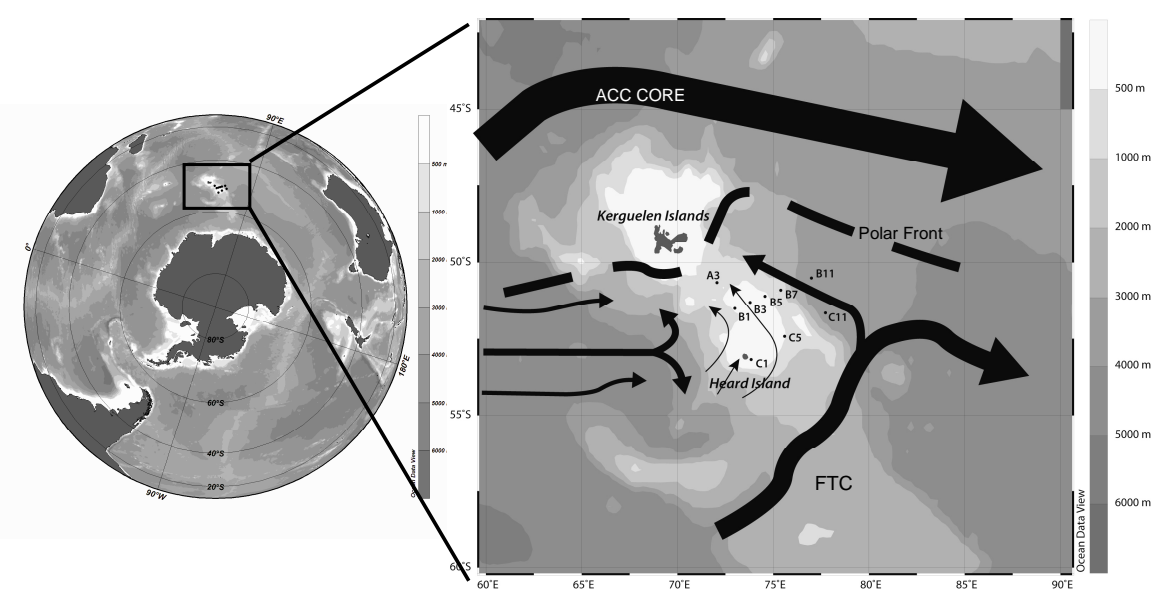

(a)

(b)

Fig. 1. (a) The black rectangle denotes the location of the KEOPS study area in the Southern Ocean, (b) location of the stations. Black arrows describe the general mean circulation around and above the plateau (Park et al., 2008b). Scale represents the bathymetry of the study area (in m). ACC represents the Antarctic Circumpolar Current and FTC represents the Fawn Through Current. Figure prepared using Ocean Data View (Schlitzer, 2007).

blank was $0.02 \pm 0.02 \mathrm{nmol} \mathrm{L}^{-1}(n=9)$. The individual contributions to the total blank from ultrapure hydrochloric acid (MERCK), suprapure ammonia (MERCK), and ammonium acetate buffer purified three times through a 8-HQ column were determined by addition of increasing amounts of these reagents to the sample and were lower than our detection limit. The accuracy of the method was assessed by analysing the DFe standards collected during the Sampling and Analysis of $\mathrm{Fe}$ (SAFe) cruise (Johnson et al., 2007). The two samples analysed (S1 and D2) gave values of $0.117 \pm 0.009$ $(n=3)$ and $0.82 \pm 0.06(n=3) \mathrm{nmol} \mathrm{L}^{-1}$, respectively, for the surface and the deep waters standards, which are in agreement with the certified values of $0.099 \pm 0.020$ and $0.91 \pm 0.07 \mathrm{nmol} \mathrm{L}^{-1}$, respectively (Johnson et al., 2006).

Samples for total particulate iron (TPFe) were collected by over-pressurising the $12 \mathrm{~L}$ GoFlo bottles and filtering as much of the whole sample as possible through a $0.2 \mu \mathrm{m}$ pore size and $47 \mathrm{~mm}$ diameter polycarbonate membrane. Filters were acid extracted in Teflon-PFA vials (Savillex, Minnetonka USA) in $1 \mathrm{~mL}$ of concentrated ultrapure nitric acid $\left(\mathrm{HNO}_{3}\right.$, Seastar Baseline $)$ and heated for $4 \mathrm{~h}$ on a Teflon-coated hot plate at $120^{\circ} \mathrm{C}$, before analysis using Magnetic Sector Inductively Coupled Plasma-Mass Spectrometry (Finnigan ELEMENT, Bremen, Germany) (following adaptation of the methods reported in Cullen and Sherell 1999; Townsend et al., 2000; Lannuzel et al., 2010). Given that a mixture of strong acids ( $\mathrm{HF}, \mathrm{HCl}, \mathrm{HNO}_{3}$ ) was not used, we assume that the TPFe fraction measured here therefore represents the most leachable particulate Fe pool, probably mostly comprised of material of biogenic origin (Lannuzel et al., 2010).

\section{Results}

Total Dissolvable Fe concentrations are reported in Table 1. TDFe vertical profiles for the 9 stations are presented in Fig. 2. At station C1, close to Heard Island, very high values were observed throughout the water column (concentrations ranged from $329 \pm 10$ to $770 \pm 8 \mathrm{nmol} \mathrm{L}^{-1}$ ). This atypical station is discussed separately from the others.

TDFe concentrations at stations located above the plateau (A3, B1, B3, B5, B7 and C5) were higher than offshore stations (B11 and C11). Above the plateau, concentrations varied from $0.90 \pm 0.01(\mathrm{~B} 7,80 \mathrm{~m})$ to $65.6 \pm 1.00 \mathrm{nmol} \mathrm{L}^{-1}$ $(\mathrm{C} 5,450 \mathrm{~m})$ whereas outside the plateau values ranged from $0.34 \pm 0.05$ (B11, $40 \mathrm{~m}$ ) to $2.23 \pm 0.07 \mathrm{nmol} \mathrm{L}^{-1}$ (C11, $600 \mathrm{~m})$.

Stations outside the plateau exhibited concentrations typical of the open Southern Ocean. Our values are in the same range as those measured by Sarthou et al. (1997) in the Indian sector and Sedwick et al. (1997) in the Australian sector (see Table 2).

Higher TDFe concentrations were measured at stations located above the plateau, especially at stations located in the southeastern part, East of Heard Island: 66 and $41 \mathrm{nmol} \mathrm{L}^{-1}$ at 450 and $500 \mathrm{~m}$ respectively, at C5 station (bottom depth $561 \mathrm{~m}$ ); $38 \mathrm{nmol} \mathrm{L}^{-1}$ at $400 \mathrm{~m}$ at B3 station (bottom depth $450 \mathrm{~m}$ ), see Table 1 and Fig. 2. In the literature, such high values $\left(38-66 \mathrm{nmol} \mathrm{L}^{-1}\right)$ were not often reported even in $\mathrm{Fe}$ enriched waters (see Table 2). Concentrations reaching $6.2 \mathrm{nmol} \mathrm{L}^{-1}$ suggested lateral advection of iron-rich shelf water (Sarthou et al., 1997). Values up to $12.5 \mathrm{nmol} \mathrm{L}^{-1}$ were measured south of Tasmania, supporting a sedimentary 
Table 1. Total dissolvable iron (TDFe), apparent particulate iron $\left(\mathrm{Fe}_{\mathrm{app}}\right)$ and location of the sampling stations. $\mathrm{Fe}_{\mathrm{app}}$ is calculated using dissolved iron (DFe) values from Blain et al. (2008). Uncertainties on the TDFe concentrations correspond to standard deviation of triplicate measurements of the sample measured 3 times. Uncertainties on the $\mathrm{Fe}_{\text {app }}$ correspond to the sum of the TDFe and DFe uncertainties. nd represents "not determined" values.

\begin{tabular}{|c|c|c|c|c|c|c|}
\hline Station & Latitude & Longitude & Depth (m) & $\mathrm{TDFe}\left(\mathrm{nmol} \mathrm{L}^{-1}\right)$ & $\mathrm{Fe}_{\text {app }}\left(\mathrm{nmol} \mathrm{L}{ }^{-1}\right)$ & $\% \mathrm{Fe}_{\text {app }} / \mathrm{TDFe}$ \\
\hline \multirow[t]{9}{*}{ A3 } & $50.65^{\circ} \mathrm{S}$ & $72.07^{\circ} \mathrm{E}$ & 40 & $1.22 \pm 0.01$ & $0.97 \pm 0.02$ & $90 \%$ \\
\hline & & & 80 & $1.07 \pm 0.01$ & $0.82 \pm 0.01$ & $87 \%$ \\
\hline & & & 120 & $1.73 \pm 0.09$ & nd & nd \\
\hline & & & 150 & $2.18 \pm 0.04$ & $1.96 \pm 0.04$ & $95 \%$ \\
\hline & & & 200 & $2.16 \pm 0.01$ & $1.85 \pm 0.01$ & $91 \%$ \\
\hline & & & 300 & $3.45 \pm 0.03$ & $3.15 \pm 0.03$ & $94 \%$ \\
\hline & & & 350 & $5.09 \pm 0.15$ & $4.75 \pm 0.15$ & $95 \%$ \\
\hline & & & 400 & $6.48 \pm 0.06$ & nd & nd \\
\hline & & & 450 & $9.63 \pm 0.03$ & nd & nd \\
\hline \multirow[t]{7}{*}{ B1 } & $51.5^{\circ} \mathrm{S}$ & $73.0^{\circ} \mathrm{E}$ & 40 & $2.72 \pm 0.04$ & $2.64 \pm 0.04$ & $97 \%$ \\
\hline & & & 80 & $1.75 \pm 0.02$ & $1.70 \pm 0.02$ & $97 \%$ \\
\hline & & & 120 & $1.96 \pm 0.06$ & $1.89 \pm 0.06$ & $97 \%$ \\
\hline & & & 150 & $2.97 \pm 0.04$ & $2.90 \pm 0.04$ & $98 \%$ \\
\hline & & & 250 & $4.35 \pm 0.02$ & $4.19 \pm 0.03$ & $96 \%$ \\
\hline & & & 300 & $5.68 \pm 0.06$ & $5.51 \pm 0.06$ & $97 \%$ \\
\hline & & & 350 & $7.35 \pm 0.21$ & $7.15 \pm 0.21$ & $97 \%$ \\
\hline \multirow[t]{8}{*}{ B3 } & $51.3^{\circ} \mathrm{S}$ & $73.8^{\circ} \mathrm{E}$ & 40 & $2.22 \pm 0.02$ & $2.10 \pm 0.02$ & $95 \%$ \\
\hline & & & 80 & $2.92 \pm 0.02$ & $2.81 \pm 0.03$ & $96 \%$ \\
\hline & & & 120 & $2.60 \pm 0.14$ & $2.52 \pm 0.14$ & $97 \%$ \\
\hline & & & 150 & $3.07 \pm 0.02$ & $2.96 \pm 0.03$ & $96 \%$ \\
\hline & & & 200 & $2.83 \pm 0.02$ & $2.68 \pm 0.02$ & $95 \%$ \\
\hline & & & 300 & $3.97 \pm 0.05$ & $3.72 \pm 0.06$ & $94 \%$ \\
\hline & & & 350 & $13.64 \pm 0.44$ & $13.40 \pm 0.45$ & $98 \%$ \\
\hline & & & 400 & $38.10 \pm 1.32$ & $37.75 \pm 1.32$ & $99 \%$ \\
\hline \multirow[t]{7}{*}{ B5 } & $51.1^{\circ} \mathrm{S}$ & $74.58^{\circ} \mathrm{E}$ & 43 & $2.73 \pm 0.14$ & nd & nd \\
\hline & & & 80 & $4.67 \pm 0.02$ & $4.62 \pm 0.02$ & $99 \%$ \\
\hline & & & 93 & $3.79 \pm 0.02$ & nd & nd \\
\hline & & & 120 & $3.39 \pm 0.09$ & $3.34 \pm 0.10$ & $98 \%$ \\
\hline & & & 150 & $2.39 \pm 0.08$ & $2.30 \pm 0.08$ & $96 \%$ \\
\hline & & & 200 & $3.34 \pm 0.05$ & $3.26 \pm 0.05$ & $97 \%$ \\
\hline & & & 300 & $4.26 \pm 0.11$ & $4.09 \pm 0.11$ & $96 \%$ \\
\hline \multirow[t]{8}{*}{ B7 } & $50.9^{\circ} \mathrm{S}$ & $75.4^{\circ} \mathrm{E}$ & 40 & $4.30 \pm 0.07$ & $4.25 \pm 0.08$ & $99 \%$ \\
\hline & & & 80 & $0.90 \pm 0.01$ & $0.76 \pm 0.02$ & $85 \%$ \\
\hline & & & 150 & $2.18 \pm 0.06$ & nd & nd \\
\hline & & & 200 & $1.59 \pm 0.01$ & $1.33 \pm 0.02$ & $84 \%$ \\
\hline & & & 300 & $2.43 \pm 0.02$ & $2.12 \pm 0.03$ & $87 \%$ \\
\hline & & & 400 & $3.90 \pm 0.01$ & $3.57 \pm 0.03$ & $91 \%$ \\
\hline & & & 450 & $4.93 \pm 0.03$ & $4.63 \pm 0.04$ & $94 \%$ \\
\hline & & & 500 & $3.83 \pm 0.02$ & $3.49 \pm 0.03$ & $91 \%$ \\
\hline \multirow[t]{8}{*}{ B11 } & $50.5^{\circ} \mathrm{S}$ & $77.0^{\circ} \mathrm{E}$ & 40 & $0.34 \pm 0.05$ & nd & nd \\
\hline & & & 150 & $0.43 \pm 0.02$ & nd & nd \\
\hline & & & 200 & $0.71 \pm 0.01$ & nd & nd \\
\hline & & & 400 & $0.39 \pm 0.01$ & nd & nd \\
\hline & & & 600 & $0.89 \pm 0.02$ & nd & nd \\
\hline & & & 800 & $0.46 \pm 0.01$ & nd & nd \\
\hline & & & 1000 & $0.62 \pm 0.01$ & nd & nd \\
\hline & & & 2000 & $1.01 \pm 0.01$ & nd & nd \\
\hline \multirow[t]{5}{*}{$\mathrm{C} 1$} & $53.18^{\circ} \mathrm{S}$ & $73.85^{\circ} \mathrm{E}$ & 20 & $364.44 \pm 9.10$ & $363.66 \pm 9.11$ & $100 \%$ \\
\hline & & & 40 & $328.60 \pm 9.50$ & $327.79 \pm 9.50$ & $100 \%$ \\
\hline & & & 80 & $366.67 \pm 26.30$ & $365.89 \pm 26.35$ & $100 \%$ \\
\hline & & & 100 & $770.22 \pm 8.10$ & nd & nd \\
\hline & & & 120 & $420.08 \pm 16.10$ & $419.27 \pm 16.10$ & $100 \%$ \\
\hline
\end{tabular}


Table 1. Continued.

\begin{tabular}{|c|c|c|c|c|c|c|}
\hline Station & Latitude & Longitude & Depth (m) & TDFe $\left(\mathrm{nmol} \mathrm{L}^{-1}\right)$ & $\mathrm{Fe}_{\mathrm{app}}\left(\mathrm{nmol} \mathrm{L}^{-1}\right)$ & $\% \mathrm{Fe}_{\mathrm{app}} / \mathrm{TDFe}$ \\
\hline \multirow[t]{9}{*}{ C5 } & $52.42^{\circ} \mathrm{S}$ & $75.6^{\circ} \mathrm{E}$ & 40 & $2.19 \pm 0.05$ & $2.13 \pm 0.05$ & $97 \%$ \\
\hline & & & 80 & $5.02 \pm 0.03$ & $4.95 \pm 0.03$ & $99 \%$ \\
\hline & & & 120 & $2.22 \pm 0.03$ & $2.14 \pm 0.03$ & $96 \%$ \\
\hline & & & 150 & $4.10 \pm 0.02$ & $4.02 \pm 0.02$ & $98 \%$ \\
\hline & & & 200 & $18.42 \pm 3.80$ & $18.16 \pm 3.80$ & $99 \%$ \\
\hline & & & 300 & $17.29 \pm 2.40$ & $16.99 \pm 2.40$ & $98 \%$ \\
\hline & & & 400 & $15.97 \pm 1.50$ & $15.60 \pm 1.51$ & $98 \%$ \\
\hline & & & 450 & $65.59 \pm 1.00$ & $65.07 \pm 1.02$ & $99 \%$ \\
\hline & & & 500 & $51.42 \pm 8.00$ & $50.84 \pm 8.01$ & $99 \%$ \\
\hline \multirow[t]{9}{*}{$\mathrm{C} 11$} & $51.65^{\circ} \mathrm{S}$ & $77.73^{\circ} \mathrm{E}$ & 40 & $0.97 \pm 0.03$ & $0.84 \pm 0.03$ & $87 \%$ \\
\hline & & & 80 & $0.98 \pm 0.01$ & $0.91 \pm 0.02$ & $93 \%$ \\
\hline & & & 120 & $1.00 \pm 0.01$ & nd & nd \\
\hline & & & 200 & $0.56 \pm 0.02$ & $0.49 \pm 0.02$ & $87 \%$ \\
\hline & & & 400 & $0.53 \pm 0.01$ & $0.47 \pm 0.01$ & $89 \%$ \\
\hline & & & 500 & $1.74 \pm 0.02$ & nd & nd \\
\hline & & & 600 & $2.23 \pm 0.07$ & $1.99 \pm 0.07$ & $89 \%$ \\
\hline & & & 800 & $1.55 \pm 0.01$ & $1.28 \pm 0.01$ & $82 \%$ \\
\hline & & & 1000 & $2.02 \pm 0.01$ & $1.76 \pm 0.01$ & $87 \%$ \\
\hline
\end{tabular}

Table 2. Range of total dissolvable iron (TDFe), apparent particulate iron $\left(\mathrm{Fe}_{\mathrm{app}}\right)$ and percentage of $\mathrm{Fe}_{\mathrm{app}}$ in the total dissolvable fraction in the water column for different seasons and sectors of the Southern Ocean ((a) Sarthou et al., 1997, (b) Löscher et al., 1997, (c) Sedwick et al., 1997, (d) Sedwick et al., 2008), for a coastal environment in the Pacific Ocean ((e) Chase et al., 2005, (f) Johnson et al., 2001, (g) Fitzwater et al., 2003) and for the Atlantic Ocean ((h) Croot et al., 2004).

\begin{tabular}{|c|c|c|c|c|}
\hline $\begin{array}{l}{[\mathrm{Fe}]\left(\mathrm{nmol} \mathrm{L}^{-1}\right) \text { on }} \\
\text { the whole water column }\end{array}$ & Location & $\begin{array}{l}\text { Total dissolvable } \\
\text { Iron }\left(\mathrm{nmol} \mathrm{L}^{-1}\right)\end{array}$ & $\begin{array}{l}\text { Apparent particulate } \\
\text { Iron }\left(\mathrm{nmol} \mathrm{L}^{-1}\right)\end{array}$ & $\begin{array}{r}\% \\
\left(\mathrm{Fe}_{\mathrm{app}} / \mathrm{TDFe}\right)\end{array}$ \\
\hline \multirow[t]{3}{*}{ Open Ocean } & Indian Sector, summer (this study) & $0.34-2.23$ & $0.47-1.99$ & 83-93 (mean: $86 \pm 3$ ) \\
\hline & Atlantic Sector, spring (b) & $0.5-8.9$ & $0-6.86$ & $0-97$ \\
\hline & Australian Sector, summer (c) & $0.17-1.3$ & $0.02-1.07$ & $0-81$ \\
\hline \multirow[t]{5}{*}{ Fe rich waters } & Indian Sector, summer (this study) & $0.9-65.6$ & $0.8-65.1$ & 82-99 (mean: $95 \pm 5$ ) \\
\hline & Monterey Bay, California, summer (e) & $0.3-17.4$ & & \\
\hline & Monterey Bay, California, spring (f) & 25 & & $\sim 80$ \\
\hline & Monterey Bay, California (g) & $0.80-6.57$ & & \\
\hline & Equatorial Atlantic (h) & $0.3-6$ & $0-5$ & 0-80 (mean: $46 \pm 12)$ \\
\hline
\end{tabular}

source (Sedwick et al., 2008). Concentrations higher than $10 \mathrm{nmol} \mathrm{L}^{-1}$ and $25 \mathrm{nmol} \mathrm{L}^{-1}$ were reported by Chase et al. (2005) and Johnson et al. (2001) respectively, in the upwelling system of Monterey Bay, California. The higher values determined by Löscher et al. (1997) in the Atlantic sector of the Southern Ocean are explained by the upwelling of iron rich Antarctic waters

Apparent particulate iron $\left(\mathrm{Fe}_{\mathrm{app}}\right)$ concentrations, calculated by subtracting $\mathrm{DFe}$ values measured during the cruise (Blain et al., 2008) from TDFe, are reported in Table 1. $\mathrm{Fe}_{\text {app }}$ is defined as the iron adsorbed on lithogenic or biogenic par- ticles, the biogenic iron and the labile lithogenic particulate iron (de Baar et al., 1999) plus the refractory colloids included in the dissolved fraction and that were not measured on board after a few days of acid storage. $\mathrm{Fe}_{\text {app }}$ represents between 82 and $99 \%$ of the TDFe (mean value $95 \pm 5 \%$ ) above the plateau and between 83 and $93 \%$ (mean value $86 \pm 3 \%$ ) outside the plateau with no difference between surface and deep water (see Table 1). This suggests that particles or refractory colloids largely dominated the iron pool. Such high percentages were previously observed in the open ocean and in enriched waters but with a larger variability. Löscher et 

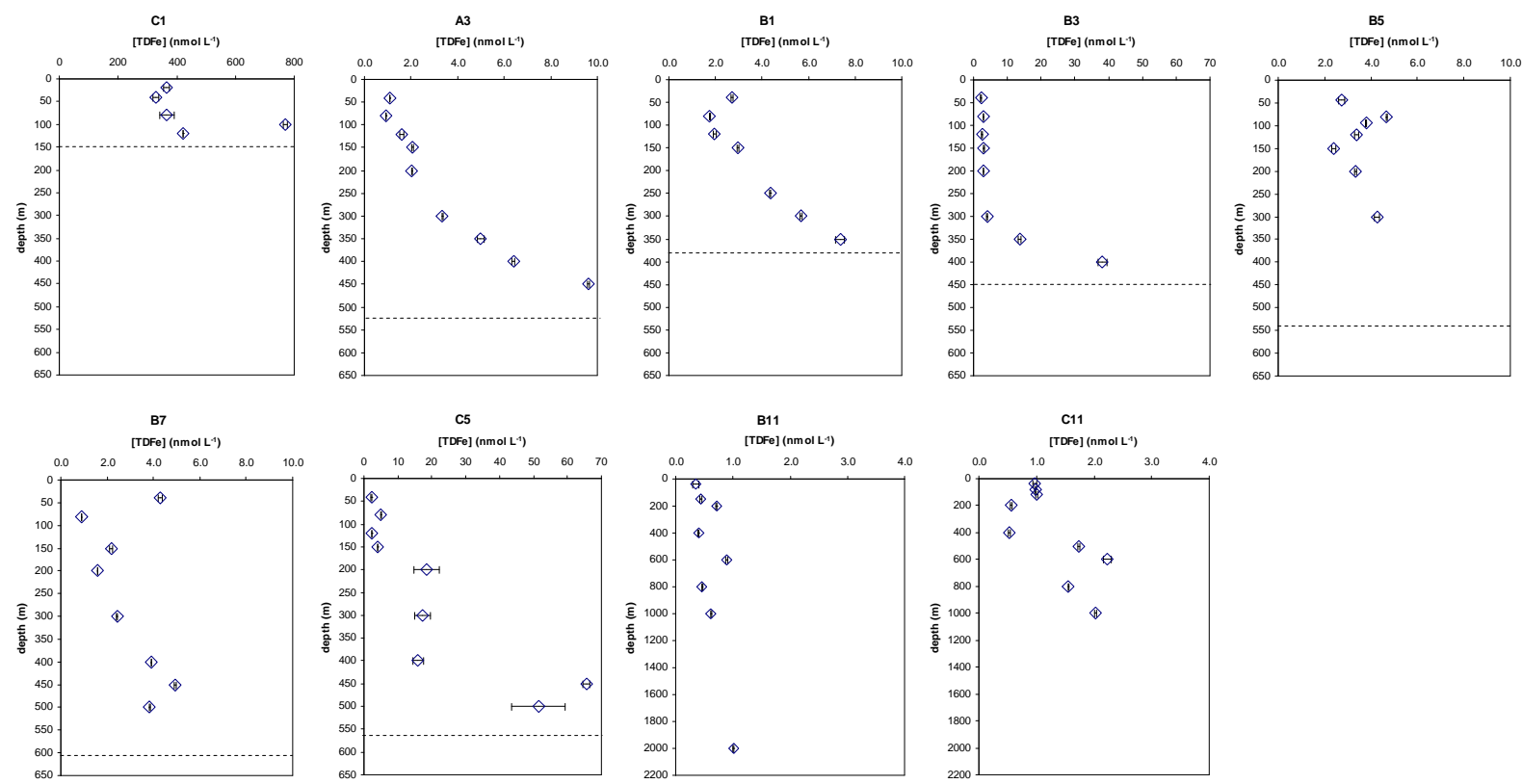

Fig. 2. Vertical profiles of total dissolvable iron (TDFe, $\mathrm{nmol} \mathrm{L}^{-1}$ ) at $\mathrm{C} 1$ station (near Heard Island), above the plateau (A3, B1, B3, B5, B7 and C5) and outside the plateau (B11 and C11). Depicted are mean values \pm 1 SD. Depth and concentration scales are not the same for all the stations. For stations located above the plateau, the dashed lines represent the bottom depth.

al. (1997), Sedwick et al. (1997) and Croot et al. (2004) observed percentages of $\mathrm{Fe}_{\text {app }}$ varying between 0 and more than $80 \%$ in the Atlantic sector of the Southern Ocean, the Australian sector of the Southern Ocean and the Equatorial sector of the Atlantic Ocean, respectively (Table 2).

\section{Discussion}

The onboard study of the concentration of DFe above the plateau highlighted the existence of a deep dissolved ironrich reservoir below the mixed layer (Blain et al., 2007). The main sources of DFe in the surface waters were identified to be diapycnal diffusive mixing and the utilisation of the winter stock (Blain et al., 2008), but a comparison of iron supply versus iron demand of phytoplankton suggested that an additional iron source was present, and that was possibly the dissolution of lithogenic particles (Blain et al. 2007, 2008; Sarthou et al., 2008). Additionally, the study of the rareearth elements (REE) showed that Heard Island could be a significant source of lithogenic material in the water column above the plateau (Zhang et al., 2008). This source is also evidenced by elevated ${ }^{228} \mathrm{Ra}$ activities above the plateau (van Beek et al., 2008). The lateral advection of water masses that have been in contact with the continental shelf of Heard Island should thus be considered as a possible source of particulate and dissolved iron above the plateau. In the following section, we focus on the $\mathrm{Fe}_{\text {app }}$ and the $\mathrm{DFe}$ fractions. The different sources of particulate and dissolved iron above the plateau are investigated and a budget of iron is presented.
The main objectives of this budget were to better define the geochemical cycle of Fe during the KEOPS cruise, and notably to explore the role of the TDFe as a tracer of lithogenic inputs coming from Heard Island, a mechanisms shown for other tracers (REE, ${ }^{228} \mathrm{Ra} . .$. ) (van Beek et al., 2008; Zhang et al., 2008) but not for Fe yet. It was also used to refine the $\mathrm{C}$ sequestration efficiency. The question of the bioavailability of these particles is also discussed.

\subsection{Budget of iron above the Kerguelen plateau}

\subsubsection{Description of the model}

A two box-model including pools and fluxes of dissolved and particulate iron was used to determine an iron budget above the Kerguelen plateau. A steady state was assumed to allow the construction of this budget. Results of the calculated fluxes will give information on the relevance of this assumption. The model is illustrated in Fig. 3a. The area covered by these boxes is the surface plateau (i.e. $45000 \mathrm{~km}^{2}$ ). The surface box represents the upper $150 \mathrm{~m}$ of the water column. This depth stratum was chosen in accordance with the study of Blain et al. (2008) who observed a higher vertical gradient of DFe below $150 \mathrm{~m}$ for the stations located above the plateau. The deep box represents the depth stratum $150 \mathrm{~m}$ - bottom depth, with increasing depth from the incoming (325 m depth) to the exit (500 m depth) of the box in accordance with the topography of the plateau (Park et al., 2008a). All the sources and sinks of dissolved and particulate iron in the two boxes are listed below with the corresponding 
inflowing and outflowing fluxes. The sedimentary source which could play a significant role is taken into account for the dissolved pool but data are lacking for the particulate flux calculation. Finally, the isopycnal mixing is neglected. Indeed, Maraldi et al. (2009) studied the influence of the short term $(\sim$ less than a week) lateral mixing on the phytoplankton bloom over the Kerguelen Plateau. They concluded that the spatial pattern of the bloom was delimited by a barrier of high lateral mixing due essentially to tides, with minor contributions from Ekman transport, geostrophy or barotropic atmospheric forced currents. Mongin et al. (2008) also showed that the effect of lateral diffusion has little effect on the overall carbon and iron budgets. We have therefore decided to make the same assumptions for our iron budget model.

The four following equations are used to describe the variation with time of dissolved and particulate iron in surface and deep waters.

$$
\begin{gathered}
\frac{d[\mathrm{DFe}]_{1}}{d t} \cdot V 1=A_{d} \cdot S+\left(\mathrm{Fw}_{1} \cdot[\mathrm{DFe}]_{C}\right)_{1}+\mathrm{DMd}+\mathrm{WSd} \\
-\mathrm{Fw}_{1} \cdot[\mathrm{DFe}]_{\text {plateau } 1}-\mathrm{E} 1
\end{gathered}
$$

$$
\begin{aligned}
\frac{d[\mathrm{DFe}]_{2}}{d t} \cdot V 2 & =\left(\mathrm{Fw}_{1} \cdot[\mathrm{DFe}]_{C}\right)_{2}+\left(\mathrm{Fw}_{2} \cdot[\mathrm{DFe}]_{\mathrm{C}}\right)_{2} \\
+\mathrm{Sed}_{d} & -\mathrm{DMd}-\mathrm{WSd}-\mathrm{Fw}_{2} \cdot[\mathrm{DFe}]_{\text {plateau } 2}-\mathrm{E} 2
\end{aligned}
$$

$$
\begin{gathered}
\frac{d\left[\mathrm{Fe}_{\mathrm{app}}\right]_{1}}{d t} \cdot V 1=A_{p} \cdot S+\left(\mathrm{Fw}_{1} \cdot\left[\mathrm{Fe}_{\mathrm{app}}\right]_{C}\right)_{1}+\mathrm{DMp}+\mathrm{E} 1 \\
-\mathrm{Fw}_{1} \cdot\left[\mathrm{Fe}_{\mathrm{app}}\right]_{\text {plateau } 1}-\mathrm{F} 1
\end{gathered}
$$

$$
\begin{gathered}
\frac{d\left[\mathrm{Fe}_{\mathrm{app}}\right]_{2}}{d t} \cdot V 2=\left(\mathrm{Fw}_{1} \cdot\left[\mathrm{Fe}_{\mathrm{app}}\right]_{C}\right)_{2}+\left(\mathrm{Fw}_{2} \cdot\left[\mathrm{Fe}_{\mathrm{app}}\right]_{C}\right)_{2} \\
+\mathrm{E} 2+\mathrm{F} 1-\mathrm{DMp}-\mathrm{Fw}_{2} \cdot\left[\mathrm{Fe}_{\mathrm{app}}\right]_{\text {plateau2 }}-\mathrm{F} 2
\end{gathered}
$$

Numbers 1 and 2 correspond to the surface and the deep layer respectively. " $V$ " and " $S$ " represent the box volume and the box surface. Letters " $d$ " and " $p$ " refer to the dissolved and the particulate fluxes. " $A$ " represents the atmospheric inputs. "Fw" represents the water flux. "Plateau" represents the mean concentration above the plateau and " $C$ " represents the mean concentration along transect $C$. "DM" represents the inflowing flux in the surface layer coming from the diapycnal mixing, "WS" refers to the winter stock. "E" corresponds to the net fluxes exchanged between dissolved and particulate fraction. "F" refers to the particle fluxes at the bottom of each box.

To estimate lateral inflowing and outflowing fluxes of iron in our model, we used the mean current velocity estimated by Park et al. (2008b) above the plateau $\left(4.0 \pm 0.5 \mathrm{~cm} \mathrm{~s}^{-1}\right)$. The corresponding hydrological fluxes $(\mathrm{Fw})$ are calculated by multiplying this current by the section of the box $(350 \mathrm{~km}$ width and $150 \mathrm{~m}$ depth for the upper box, $350 \mathrm{~km}$ width and $175 \mathrm{~m}$ and $350 \mathrm{~m}$ depth for the entrance and the exit of the deep box, respectively). These water fluxes are multiplied by the mean dissolved or particulate iron concentrations along the transect $C$ or above the plateau, in the upper or deep boxes. These mean concentrations are reported in Table 3 . We assumed that the water flux transporting dissolved and apparent particulate iron from the transit $C$ in the surface box is uniform over the $500 \mathrm{~m}$ water column leading to the two different fluxes $\left(\mathrm{Fw}_{1} \cdot[\mathrm{DFe}]_{C}\right)_{1}$ and $\left(\mathrm{Fw}_{1} \cdot[\mathrm{DFe}]_{C}\right)_{2}$ for the $\mathrm{DFe}$, and $\left(\mathrm{Fw}_{1} \cdot\left[\mathrm{Fe}_{\mathrm{app}}\right]_{C}\right)_{1}$ and $\left(\mathrm{Fw}_{1} \cdot\left[\mathrm{Fe}_{\mathrm{app}}\right]_{C}\right)_{2}$ for the $\mathrm{Fe}_{\mathrm{app}}$ fraction (Fig. 3a). Figure $3 \mathrm{~b}$ displays the results of the calculated stocks and fluxes.

\subsubsection{Budget calculation}

\section{Atmospheric inputs}

One of the main external sources of iron to the surface waters of the open ocean is aeolian dust deposition (Jickells et al., 2005). During the cruise, aerosols were collected to estimate atmospheric fluxes to the Southern Ocean, and in particular iron fluxes over the study area (Wagener et al., 2008). A total iron flux (dry + wet) of $23 \pm 9 \mathrm{nmol} \mathrm{m}^{-2} \mathrm{~d}^{-1}$ was estimated. Assuming a solubility ranging from 1 to $10 \%$ (Bonnet and Guieu, 2004; Baker and Jickells, 2006), the atmospheric dissolved iron flux over the Kerguelen plateau can be estimated to be $0.2-3.2 \mathrm{nmol} \mathrm{m}^{-2} \mathrm{~d}^{-1}$ (Wagener et al., 2008). A mean value of $1.7 \pm 2.1 \mathrm{nmol} \mathrm{m}^{-2} \mathrm{~d}^{-1}$ is considered hereafter. These fluxes are low compared to those calculated during the Crozex and FeCycle cruises, which were $100 \mathrm{nmol} \mathrm{m}^{-2} \mathrm{~d}^{-1}$ (Planquette et al., 2007) and 7.58$75.8 \mathrm{nmol} \mathrm{m}^{-2} \mathrm{~d}^{-1}$, respectively, assuming a $1-10 \%$ dissolution of the total flux given by Boyd et al. (2005). The particulate iron flux (90-99\% of the total flux) during KEOPS was estimated to be $12.6-31.7 \mathrm{nmol} \mathrm{m}^{-2} \mathrm{~d}^{-1}$ with a mean value of $22.2 \pm 13.5 \mathrm{nmol} \mathrm{m}^{-2} \mathrm{~d}^{-1}$. Over an area of $45000 \mathrm{~km}^{2}$, the atmospheric fluxes $A d \cdot S$ and $A p \cdot S$ equal $76.5 \pm 94.5 \mathrm{~mol} \mathrm{~d}^{-1}$ and $999 \pm 607 \mathrm{~mol} \mathrm{~d}^{-1}$ for the dissolved and particulate iron, respectively. Given that the other particulate fluxes calculated in our budget represent apparent particulate fluxes, this atmospheric flux may be overestimation.

\section{Diapycnal diffusive fluxes}

The enrichment of DFe and $\mathrm{Fe}_{\mathrm{app}}$ for the stations located above the plateau (see Fig. 2) clearly indicates an input of iron from the bottom of the water column. Park et al. (2008b) estimate a vertical eddy diffusivity $(\mathrm{Kz})$ of $3.8 \pm 2.4 \times 10^{-4} \mathrm{~m}^{2} \mathrm{~s}^{-1}$ in the seasonal pycnocline $(80 \mathrm{~m}<$ $z<180 \mathrm{~m}$ ) at A3 using a Thorpe scale analysis. By multiplying this coefficient by the vertical gradient of $\mathrm{Fe}_{\text {app }}$ calculated at this station $\left(8.6 \mathrm{nmol} \mathrm{m}^{-4}\right.$ between 80 and $\left.200 \mathrm{~m}\right)$, a diapycnal mixing of $283 \pm 178 \mathrm{nmol} \mathrm{m}^{-2} \mathrm{~d}^{-1}$ can be estimated. Above the plateau, $\mathrm{Kz}$ was only estimated at A3 station. Assuming that the diapycnal mixing is homogeneous over all the plateau area, we calculate a flux of particles (DMp) of $12735 \pm 8010 \mathrm{~mol} \mathrm{~d}^{1}$. The vertical supply calculated for DFe at $A 3$ is $31 \mathrm{nmol} \mathrm{m}^{-2} \mathrm{~d}^{-1}$ (Blain et al., 2008). With the same 
Table 3. Mean dissolved and apparent particulate iron concentrations calculated above and below $150 \mathrm{~m}$, for all the stations located above the plateau and for the stations located along transect $C$.

\begin{tabular}{lcccc}
\hline & \multicolumn{2}{c}{ Upper box } & \multicolumn{2}{c}{ Deep box } \\
& $\mathrm{Fe}_{\text {app }}\left(\mathrm{nmol} \mathrm{L}^{-1}\right)$ & $\mathrm{DFe}\left(\mathrm{nmol} \mathrm{L}^{-1}\right)$ & $\mathrm{Fe}_{\mathrm{app}}\left(\mathrm{nmol} \mathrm{L}^{-1}\right)$ & $\mathrm{DFe}\left(\mathrm{nmol} \mathrm{L}^{-1}\right)$ \\
\hline Transect $C^{*}$ & $186 \pm 39$ & $0.44 \pm 0.03$ & $33.74 \pm 23.17$ & $0.41 \pm 0.14$ \\
Above the plateau & $2.43 \pm 1.04$ & $0.09 \pm 0.03$ & $6.66 \pm 8.13$ & $0.23 \pm 0.08$ \\
\hline
\end{tabular}

* Values in the upper box correspond to the mean of the two stations C1 and C5. Values in the deep box correspond to the mean of the single station C5.

assumption that this mixing is homogeneous, we calculate a dissolved flux (DMd) of $1395 \mathrm{~mol} \mathrm{~d}^{-1}$.

\section{Winter mixing}

The second mechanism of fertilization mentioned by Blain et al. $(2007,2008)$ for dissolved iron is the utilisation of the winter stock above the plateau. During winter, the strong winds allow a greater mixing of the surface waters. The thickness of the mixed layer can reach $200 \mathrm{~m}$. As deep water contains higher concentration of iron than surface water (Blain et al., 2008), at the beginning of the spring, surface water is enriched in iron. This stock is called winter stock. To calculate the stock of iron potentially available for phytoplankton growth, the thermal structure of the water column has to be known. The temperature minimum is indicative of the winter concentration $\left(\mathrm{C}_{\text {winter }}\right)$. The mean concentration of DFe measured within the mixed layer is called the summer concentration $\left(\mathrm{C}_{\text {summer }}\right)$. The winter stock utilization (nmol m $\mathrm{m}^{-2} \mathrm{~d}^{-1}$ ) is calculated using the following equation $\left(\mathrm{C}_{\text {winter }}-\mathrm{C}_{\text {summer }}\right) \cdot \mathrm{MLD} / 90$ where MLD represents the mean mixed layer depth (70 m at A3) and 90 days is the duration of the bloom. Winter stock utilization was $52 \mathrm{nmol} \mathrm{m}^{-2} \mathrm{~d}^{-1}$ for the DFe (Blain et al., 2008). Assuming that this flux is homogeneous over all the surface of the plateau, we calculate a winter mixing flux (WSd) of $2340 \mathrm{~mol} \mathrm{~d}^{-1}$ for the dissolved iron.

\section{Lateral advection}

Lateral advection is a potential source of dissolved and particulate iron above the plateau. Apart from some sporadic mesoscale intrusions (Zhang et al., 2008), the circulation above the KEOPS study area rules out any transport of waters from the Kerguelen Island to the plateau (Park et al., 2008a), whereas a lateral advection from the south can be considered. General mean circulation above the plateau is described in Fig. 1. Waters that have interacted with the continental shelf of Heard Island can be transported onto the plateau. This source is also recognised for other tracers like ${ }^{228} \mathrm{Ra}$ (van Beek et al., 2008), lithogenic Ba (Jacquet el al., 2008) and rare-earth elements (Zhang et al., 2008).
Using the mean current velocity estimated by Park et al. (2008b) above the plateau in the $500 \mathrm{~m}$ water column, the hydrological fluxes $(\mathrm{Fw})$ are calculated by multiplying this current by the section of the box, leading to a surface water flux of $1.81 \pm 0.23 \times 10^{14} \mathrm{Ld}^{-1}$. For the deep box, values of $2.12 \pm 0.26 \times 10^{14} \mathrm{Ld}^{-1}$ for the inflowing flux and $4.23 \pm 0.53 \times 10^{14} \mathrm{Ld}^{-1}$ for the outflowing flux are calculated. In the surface box, multiplying the water flux by the DFe concentrations from the transect $C,\left(\mathrm{Fw}_{1} \times[\mathrm{DFe}]_{C}\right)_{1}$ and $\left(\mathrm{FW}_{1} \cdot[\mathrm{DFe}]_{C}\right)_{2}$ give values of $23.9 \pm 4.6 \times 10^{3} \mathrm{~mol} \mathrm{~d}^{-1}$ and $55.9 \pm 10.8 \times 10^{3} \mathrm{~mol} \mathrm{~d}^{-1}$, respectively. Concerning the $\mathrm{Fe}_{\mathrm{app}}$ fraction, $\left(\mathrm{Fw}_{1} \cdot\left[\mathrm{Fe}_{\mathrm{app}}\right]_{C}\right)_{1}$ and $\left(\mathrm{FW}_{1} \cdot\left[\mathrm{Fe}_{\mathrm{app}}\right]_{C}\right)_{2}$ give values of $10138 \pm 3396 \times 10^{3} \mathrm{~mol} \mathrm{~d}^{-1}$ and $23656 \pm 7923 \times 10^{3} \mathrm{~mol} \mathrm{~d}^{-1}$, respectively. In the deep box, $\left(\mathrm{Fw}_{2} \cdot[\mathrm{DFe}]_{C}\right)_{2}$ and $\left(\mathrm{Fw}_{2} \cdot\left[\mathrm{Fe}_{\mathrm{app}}\right]_{C}\right)_{2}$ give flux values of $85.9 \pm 40.4$ and $7142 \pm 5797 \times 10^{3} \mathrm{mold}^{-1}$, respectively (Fig. 3b).

\section{Sedimentary inputs}

Over the plateau, inputs of DFe in the water column from the sediment were measured during the cruise and comprised of a flux of $136 \mu \mathrm{mol} \mathrm{m} \mathrm{m}^{-2} \mathrm{~d}^{-1}$ (Blain et al., 2008), higher than previous fluxes calculated along the Californian coast (Elrod et al., 2004). This equates to a flux $\mathrm{Sed}_{d}$ of $6120 \times 10^{3} \mathrm{mold} \mathrm{d}^{-1}$, assuming it is homogeneous over the plateau.

\subsubsection{Dissolved and particulate budgets}

Results are reported in Fig. 3b. Atmospheric deposition is a negligible source of $\mathrm{Fe}_{\mathrm{app}}$ above the plateau, as already observed for DFe (Blain et al., 2008). Lateral advection is the predominant source of iron above the plateau, for $\mathrm{Fe}_{\mathrm{app}}$ but also for DFe (although the uncertainty in the calculation of this flux is important). A Tukey test with different " $n$ " values (from 3 to 50) shows that the lateral advection is always statistically different from the atmospheric and diapycnal fluxes $(p<0.001)$ for $\mathrm{DFe}$ and $\mathrm{Fe}_{\mathrm{app}}$. The corresponding fluxes are equal to $9697 \pm 3640 \times 10^{3} \mathrm{~mol} \mathrm{~d}^{-1} \quad\left(=10138-441 \times 10^{3} \mathrm{~mol} \mathrm{~d}^{-1}\right)$ and $8.3 \pm 11.6 \times 10^{3} \mathrm{~mol} \mathrm{~d}^{-1}\left(=23.9-15.6 \times 10^{3} \mathrm{~mol} \mathrm{~d}^{-1}\right)$ for $\mathrm{Fe}_{\text {app }}$ and DFe, respectively. They represent $99 \%$ and $69 \%$ 


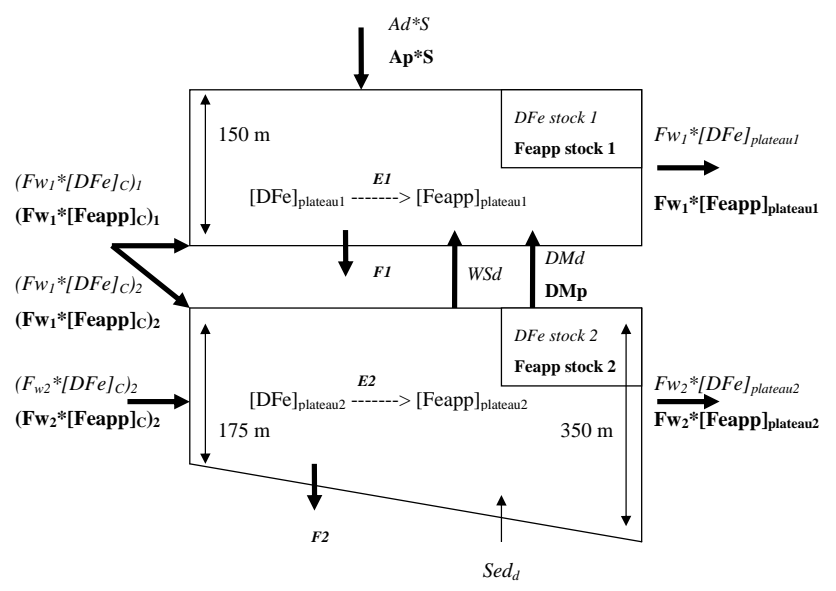

Fig. 3a. Dissolved and particulate iron 2-box budgets above the Kerguelen Plateau. Numbers 1 and 2 correspond to the surface and the deep layer, respectively. " $V$ " and " $S$ " represent the box volume and the box surface. Letters " $d$ " and " $p$ " refer to the dissolved and the particulate fluxes. " $A$ " represents the atmospheric inputs. "Fw" represents the water flux. "Plateau" represents the mean concentration above the plateau and " $C$ " represents the mean concentration along transect $C$. "DM" represents the inflowing flux in the surface layer coming from the diapycnal mixing, "WS" refers to the winter stock. "E" corresponds to the net fluxes exchanged between dissolved and particulate fraction. "F" refers to the particle fluxes at the bottom of each box. We consider a surface layer of $150 \mathrm{~m}$ and a deep layer below $150 \mathrm{~m}$ with increasing depth from the transect $C$ to the plateau. Dissolved iron fluxes are represented with numbers in italic. Particulate iron fluxes are represented with numbers in bold. Numbers in bold and italic are calculated from the resolution of the 4 equations describing the variation of dissolved and particulate iron with time.

of the total net fluxes of $\mathrm{Fe}_{\mathrm{app}}$ and DFe that enter the surface box, respectively.

The biogenic pool of $\mathrm{Fe}$ of $80 \pm 9 \mathrm{pmol} \mathrm{L}^{-1}$ calculated by Sarthou et al. (2008) represents $540 \times 10^{3} \mathrm{~mol}$ in our surface box $\left(150 \mathrm{~m}\right.$ depth, area of $\left.45000 \mathrm{~km}^{2}\right)$. It is only $3.3 \%$ of the apparent particulate iron stock calculated in our surface box $\left(16402 \times 10^{3} \mathrm{~mol}\right.$, see Fig. $\left.3 \mathrm{~b}\right)$, which suggests that the biogenic fraction is not predominant. Whatever the state of the bloom, this result confirms a posteriori our assumption of a steady state.

At steady-state, left members of the Eqs. (1-4) are equal to 0 . Values of E1, E2, F1 and F2 can be calculated by resolving these 4 equations and are reported in Fig. 3b. Values of $12.1 \pm 11.7 \times 10^{3}$ and $6160 \pm 95 \times 10^{3} \mathrm{~mol} \mathrm{~d}^{-1}$ were calculated respectively for E1 and E2.

The positive values of E1 and E2 suggest a predominant transport of iron from the dissolved to the apparent particulate fraction. Processes involved in such a transport are biological uptake, colloidal aggregation, adsorption on phytoplankton cells and scavenging by non-living particles (through adsorption, precipitation or aggregation), whereas

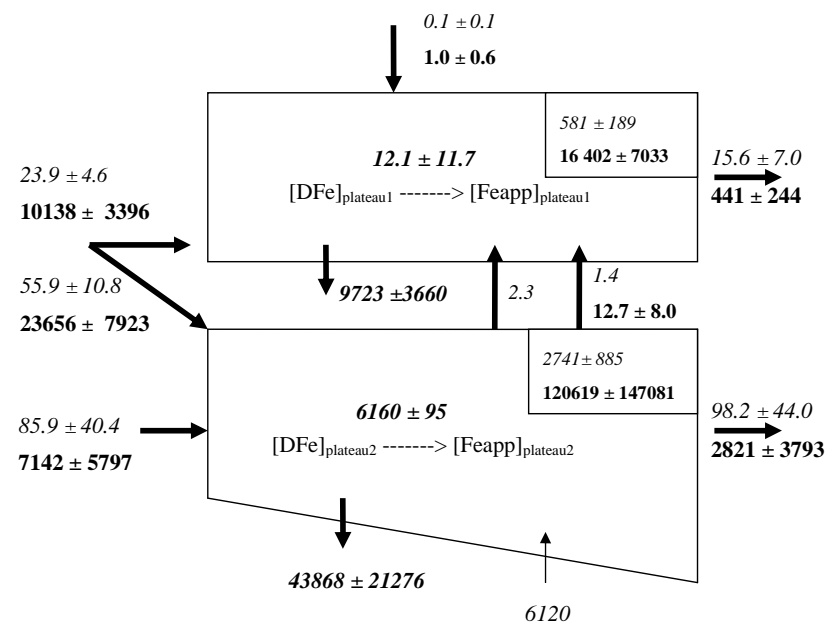

Fig. 3b. Numerical values of dissolved (in italic) and particulate (in bold) iron fluxes (in $10^{3} \mathrm{~mol} \mathrm{~d}^{-1}$ ) and stocks (in $10^{3} \mathrm{~mol}$ ). Stocks are obtained by multiplying the mean concentrations calculated above the plateau in Fig. 3a by the volume of the boxes $\left(6.75 \times 10^{12} \mathrm{~m}^{3}\right.$ for the surface box and $1.81 \times 10^{13} \mathrm{~m}^{3}$ for the deep box).

processes responsible for the transfer of apparent particulate iron to the dissolved iron pool are due to the dissolution and regeneration of particulate or colloidal iron (Sarthou and Jeandel, 2001).

Using the radiotracer ${ }^{55} \mathrm{Fe}$, the phytoplankton net $\mathrm{Fe}$ demand in the bloom (uptake minus regeneration) was equal to $208 \pm 77 \mathrm{nmol} \mathrm{m}^{-2} \mathrm{~d}^{-1}$ (Sarthou et al., 2008). Adsorption on phytoplankton cells and scavenging by non-living particles represented between 20 and $37 \%$ of the total biogenic iron (Sarthou et al., 2008), leading to a total biogenic iron flux of $260-330 \mathrm{nmol} \mathrm{m}^{-2} \mathrm{~d}^{-1}$. Assuming an area of $45000 \mathrm{~km}^{2}$, this gives a flux varying between $11.7 \times 10^{3}$ and $14.9 \times 10^{3} \mathrm{mold}^{-1}$. These values are close to $\mathrm{E} 1$ $\left(12.1 \pm 11.7 \times 10^{3} \mathrm{~mol} \mathrm{~d}^{-1}\right)$, suggesting that the dissolution of $\mathrm{Fe}_{\text {app }}$ may not be significant.

Taking into account the maximum value of the flux calculated from the ${ }^{55} \mathrm{Fe}$ experiment $\left(14.9 \times 10^{3} \mathrm{mold}^{-1}\right)$ and the minimum value of the E1 flux (ie 12.1$\left.11.7=0.4 \times 10^{3} \mathrm{~mol} \mathrm{~d}^{-1}\right), \quad$ a maximum dissolution of $14.5 \times 10^{3} \mathrm{~mol} \mathrm{~d}^{-1}$ can however be estimated. As the biogenic pool represents $3.3 \%$ of the total pool (see above), the maximum dissolution of lithogenic material is estimated to $14.0 \times 10^{3} \mathrm{mold}^{-1}$. It represents $0.14 \%$ of the total apparent particulate flux that enters in the upper box $\left(10138 \times 10^{3} \mathrm{~mol} \mathrm{~d}^{-1}\right)$. If we assume that all the DFe at $\mathrm{C} 1$ comes from the dissolution of $\mathrm{Fe}_{\mathrm{app}}$, a dissolution of $0.2 \%$ is calculated. These values are in the same range as those calculated by Bonnet and Guieu (2004) and listed by Jickells et al. (2001) for the dissolution of lithogenic Fe from atmospheric dusts. 
The exchange flux between the dissolved and apparent particulate fraction in deep waters (E2) also shows a positive value, two orders of magnitude higher than in surface waters. This suggests that scavenging and/or aggregation are predominant in the deep waters. This could be due to the high transport of particulate material in the deep box and to the inputs from the sediments.

Values of $9723 \pm 3660 \times 10^{3}$ and $43868 \pm 21276 \times 10^{3}$ mol d ${ }^{-1}$ were calculated for the particulate sinking fluxes F1 and F2, respectively. This budget suggests that most of the particles that flow above the plateau are removed from the water column by sedimentation.

The calculation of F1 allows us to estimate the residence time (RT) of apparent particulate iron (RT=PFe stock/downward PFe flux, Boyd et al., 2005). It is equal to 1.7 days in surface waters. This value is lower than that of 100 days estimated during the FeCycle experiment (Boyd et al., 2005). Residence times varying between 6 (range 2-12 days) and 62 (range 21-186) days for total iron (dissolved + particulate) were calculated in the Equatorial sector of the Atlantic Ocean (Croot et al., 2004). The shortest residence times were associated with high particulate Fe flux. In our budget, the high supply of $\mathrm{Fe}_{\mathrm{app}}$ from the weathering of Heard Island, which is rapidly removed by sinking, may explain the very low residence times calculated. It should be noted here that such a dynamic system could have implication for the scavenging of dissolved iron which could thus be overestimated in the surface box of our budget. Additionally, such a short residence time could lead to an underestimation of the apparent particulate iron concentration. Indeed, during the time required for particulate sampling, large particles ( $>20 \mu \mathrm{m}$ ) could have sunk below the level of the spigots on the Go-Flo bottles which would affect the apparent particulate iron concentration (Gardner et al., 2003).

Considering a mean dissolved iron stock in the upper $150 \mathrm{~m}$ of the water column above the plateau of $581 \times 10^{3} \mathrm{~mol}$, and a supply of DFe of $12.1 \times 10^{3} \mathrm{~mol} \mathrm{~d}^{1}$ $\left(=\left(A_{d} \cdot S+\mathrm{DM}_{d}+\mathrm{WS}_{d}+\mathrm{HS}_{d}\right)\right.$, with $\mathrm{HS}_{d}$ equal to the horizontal supply of iron above the plateau $(=(23.9-$ 15.6) $\left.\times 10^{3} \mathrm{~mol} \mathrm{~d}^{-1}\right)$ ), we estimated a DFe residence time equal to 48 days. Such a value is consistent with residence times of $\sim 10$ days-1 year observed in the North and Equatorial Atlantic Ocean (Jickells, 1999; de Baar and de Jong, 2001; Sarthou et al., 2003, 2007).

\subsection{Importance of the colloidal fraction to the bioavailability of $\mathrm{Fe}$}

Vertical profiles of total and apparent particulate iron at stations $\mathrm{A} 3$ and $\mathrm{C} 11$ are plotted in Fig. 4. For both stations, higher values are observed in the $\mathrm{Fe}_{\text {app }}$ pool compared to the TPFe pool. Indeed, $\mathrm{Fe}_{\text {app }}$ concentrations are 1.3 to 3.1 times higher than TPFe. Given that some very refractory particulate Fe remains unreactive to the TDFe handling and analysis (Powell et al., 1995), $\mathrm{Fe}_{\text {app }}$ fraction should exhibit smaller
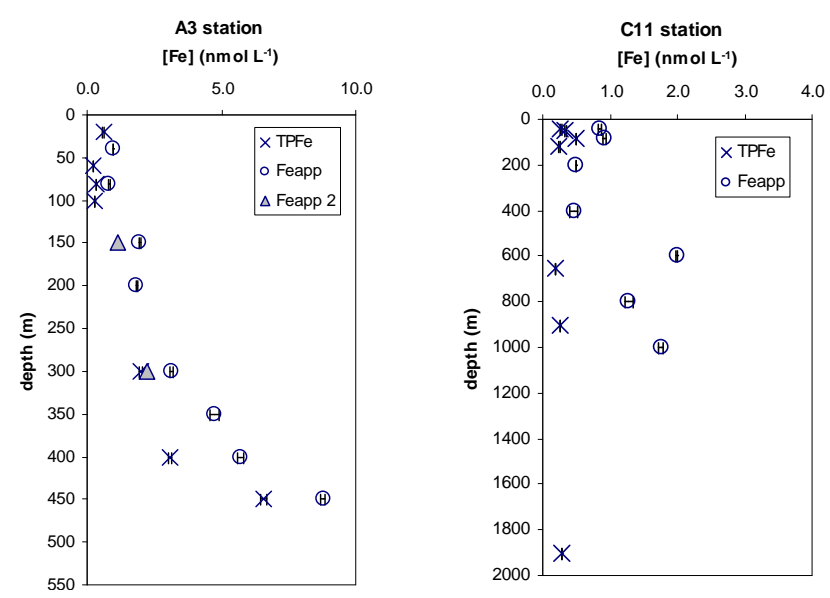

Fig. 4. Vertical profiles of total particulate (crosses) and apparent particulate iron (cercles) iron at A3 (left) and C11 (right) stations. Depicted are mean values $\pm 1 \mathrm{SD}$. The two triangles represented at station A3 correspond to the $\mathrm{Fe}_{\text {app }}$ concentrations calculated with the dissolved samples measured at the shore-based laboratory, 18 months after sampling ( $\left.\mathrm{Fe}_{\mathrm{app}} 2\right)$ (see text for more details).

concentrations than TPFe. Several reasons might explain this difference. First, for the 2 stations TPFe was sampled 10 days before TDFe and DFe. Given that the residence time of iron particles is 1.7 days, changes in the transport of particles could have occurred during this period. Second, an incomplete digestion of particulate material, leading to an underestimation of the TPFe values might have occurred, since the digestion protocol did not include a strong attack with HF acid. Finally, another possibility would be that a substantial fraction of colloidal iron was not analysed on board in the DFe pool, but was reactive to the more acidic attack and to the time storage of the TDFe samples.

A significant fraction of dissolved iron is actually thought to be in the colloidal pool (Kuma et al., 1998; Wu et al., 2001; Cullen et al., 2006). Wu et al. (2001) and Cullen et al. (2006) observed that $80-90 \%$ of the dissolved iron is present under colloidal fraction in the surface waters and $70 \%$ in the deep waters in the Atlantic Ocean.

A few duplicates of DFe samples were stored at room temperature and were analysed at the same time as the TDFe samples at the laboratory (i.e. 18 months later). DFe concentrations increased by $37-90 \%$ during these 18 months of storage. This result implies that a substantial fraction of DFe is colloidal and is only released during long acid storage. This observation confirms the work of Zhang et al. (2008) who suggest that a large pool of DFe is probably colloidal. However $\mathrm{Fe}_{\text {app }}$ still dominates the total dissolvable pool after 18 months of storage. Indeed, $\mathrm{Fe}_{\text {app }}$ represents between 54 and $99 \%$ of the TDFe (mean value $85 \pm 11 \%, n=27$ ) when considering the dissolved iron samples analysed at the laboratory. 
Only two duplicates of DFe were stored at A3 and it was possible to re-calculate the concentrations of $\mathrm{Fe}_{\text {app }}$ by using the values of DFe measured at the laboratory and to compare them with the TPFe concentrations. The new estimations of these $\mathrm{Fe}_{\text {app }}$ concentrations are presented on Fig. 4 and seem to explain the difference between the two pools. This result suggests that a significant portion of refractory colloids is present in the DFe fraction and that only a long acid storage (18 months) allows measuring this fraction.

Assuming that the colloids came from the dissolution of particulate lithogenic $\mathrm{Fe}$ at $\mathrm{C} 1$ and that the mean current velocity above the plateau is $4.0 \pm 0.5 \mathrm{~cm} \mathrm{~s}^{-1}$ (Park et al., 2008b), it takes nearly three months for the colloids to reach A3. Chen and Wang (2001) showed that freshly precipitated colloids were available to phytoplankton but aging processes (15 days) markedly reduced their availability.

Moreover, the E1 flux calculated in our budget in the surface box is consistent with the uptake by phytoplankton estimated by Sarthou et al. (2008). These calculations seem to indicate that the refractory colloidal iron present in an apparent particulate fraction is not taken up by phytoplankton.

These results give some information on the measurements of the physical speciation of iron. First, the most labile fraction of DFe measured after few hours of acidification could be the fraction that is bioavailable to the phytoplankton. Second, more than a few days of acidification are needed to measure the total dissolved iron fraction, especially in a region with high input of refractory iron. Our study indicates that 18 months of acid storage allow the measurement of the refractory colloids and determine the total particulate Fe from TDFe and DFe analyses. However, it should be noted that only digestion including HF acid (which was not used here) ensures the recovery of the most refractory and crystalline particles determined in the TPFe fraction. These observations are in agreement with the study of Bowie et al. (2004) who considered it useful to extend the storage of acidified samples to determine the total dissolved iron pool.

\subsection{Carbon sequestration efficiency}

Carbon sequestration efficiency is based on the ratio of the excess of carbon exported to the dissolved iron supplied (de Baar et al., 2005). An iron supply of $5 \times 10^{-3} \mathrm{nmol} \mathrm{m}^{-2}$, corresponding to the vertical supply and the winter stock utilization, has already been calculated by Blain et al. (2007). Taking into account the lateral advection which supplies $8.3 \times 10^{3} \mathrm{~mol} \mathrm{Fe} \mathrm{d}^{-1}\left(=(23.9-15.6) \times 10^{3} \mathrm{~mol} \mathrm{~d}^{-1}\right)$ over an area of $45000 \mathrm{~km}^{2}$ during 90 days, the contribution of the lateral supply can be estimated to be equal to $16.6 \times 10^{-3} \mathrm{nmol} \mathrm{m}^{-2}$ leading to a new estimate of dissolved iron supply of $21.6 \times 10^{-3} \mathrm{nmol} \mathrm{m}^{-2}$. This value is probably overestimated because of a possible impact of this lateral advection on the stations located outside the bloom (C11 station for example), which would lead to a smaller excess of iron. Using the excess of particulate organic carbon (POC) calculated by Blain et al. (2007) of $3317 \mathrm{nmol} \mathrm{m}^{-2}$, the new estimated sequestration efficiency is equal to $154000 \mathrm{~mol} \mathrm{C}$ $(\mathrm{mol} \mathrm{Fe})^{-1}$. With our assumptions, consideration of the lateral advection reduces the first estimate of the sequestration efficiency by 4-fold. However, this value is still appoximatively 18 -fold higher than the value calculated during the other study of a natural iron fertilisation experiment CROZEX (8640 mol C (mol Fe $)^{-1}$, Pollard et al., 2009) and is also higher than the two artificial iron fertilisation experiments SOFeX $\left(3300 \mathrm{molC}(\mathrm{molFe})^{-1}\right.$, Buesseler et al., 2004) and SERIES ( $500 \mathrm{~mol} \mathrm{C}\left(\mathrm{mol} \mathrm{Fe}^{-1}\right.$, Boyd et al., 2004). Blain et al. (2007) explained the higher carbon sequestration efficiency calculated during KEOPS than during SOFeX and SERIES by two reasons. First, it is suspected that the end of the bloom was reached during KEOPS but not during SOFeX, leading to a higher excess of carbon during KEOPS. Secondly, during mesoscale enrichment experiments a large amount of the DFe added to seawater is rapidly loss contrary to the natural iron enrichment where the input of iron is slow and continuous (Blain et al., 2007). The comparison of the carbon sequestration efficiency between the CROZEX and the KEOPS experiments is difficult because of the different methods used during the two studies to calculate iron supply and carbon export. However, Pollard et al. (2009) observed that during KEOPS, the supply of iron was 8-fold lower and the carbon exported was 10-fold higher than during CROZEX. They suggested that either a vertical mixing or a more intense lateral advection of lithogenic material could have occurred but before the late-summer observation period of KEOPS. Our study allowed us to better constrain the lateral fluxes of $\mathrm{Fe}$ over the plateau. Considering these fluxes, the sequestration efficiency previously calculated by blain et al. (2007) decreases, but still remains largely higher than during CROZEX. Taking into account the lateral supply, the supply of iron was only 2 -fold lower during KEOPS than during CROZEX. Therefore most of the difference results from differences in the excess of carbon export. Base on the data set available during both experiments it is impossible to say if this difference is real or if it results from the different approaches used. In fact when the excess of carbon export at $100 \mathrm{~m}$ are compared the factor of difference between KEOPS and CROZEX is only 5. The extrapolation at $200 \mathrm{~m}$ produces an additional factor 2 .

\section{Conclusions}

Our results suggest that TDFe in our study area predominantly consists of particles. This study also highlights the importance of the refractory colloidal fraction in the dissolved pool and emphasises the importance of extended storage to better constrain the physical speciation of Fe. The most labile fraction of DFe measured after a few days of acidification could be the fraction that is bioavailable to the phytoplankton. The total particulate Fe may be determined from TDFe 
and DFe analyses with sufficient acid storage (18 months). The study of the TDFe fraction above the Kerguelen Plateau gives information on iron sources, the physical speciation and the bioavailability of iron.

Our Fe budget also shows that the predominant source of $\mathrm{Fe}_{\text {app }}$ and DFe above the Kerguelen Plateau is the lateral advection of waters that have been in contact with the continental shelf of Heard Island. It represents $99 \%$ and $69 \%$ of the total apparent particulate and dissolved iron supply, respectively.

By taking into account the lateral advection of dissolved iron, we calculate a revised seasonal carbon sequestration efficiency of $154000 \mathrm{~mol} \mathrm{C}(\mathrm{mol} \mathrm{Fe})^{-1}, 4$ times lower than the one previously calculated by Blain et al. (2007), but still 18-fold higher than the one calculated during the natural iron fertilisation experiment CROZEX (Pollard et al., 2009). This result is also significantly higher than the carbon sequestration efficiencies obtained during artificial iron fertilisation experiments. Two reasons may explain these differences: first, if Fe is supplied in a continuous way or not, second if the bloom reached its maximum or not.

This discussion points out the need for a more accurate determination of both terms of the $\mathrm{Fe} / \mathrm{C}$ ratio. All the calculations and discussion on the efficiency ratio are based on the assumption that DFe represents the bioavailable form of iron, and clearly this assumption impacts heavily on the $\mathrm{Fe} / \mathrm{C}$ data and calculations of carbon sequestration efficiencies. The numbers and the conclusions might dramatically change if we discover in the future that this hypothesis is falsified.

Acknowledgements. We are grateful to the project coordinator Stéphane Blain, to Bernard Quéguiner, the chief scientist, and to the captain and crew of the R. V. Marion Dufresne for their support on board. We also acknowledge Thibaut Wagener for his help with sampling clean seawater. This work was supported by the Institut National des Sciences de l'Univers (INSU) and the French Polar Institute (Institut Polaire Emile Victor, IPEV). This research was partly supported by the Australian Government Cooperative Research Centres Program through the Antarctic Climate and Ecosystems CRC (ACE CRC) and the French-Australian Science and Technoloy (FAST) programme (contract number FR040170). We thank ACE CRC internal reviewers Brian Griffiths and Delphine Lannuzel for their comments. P. Boyd and an anonymous reviewer are gratefully acknowledged for their critical comments and suggestions.

Edited by: D. Turner

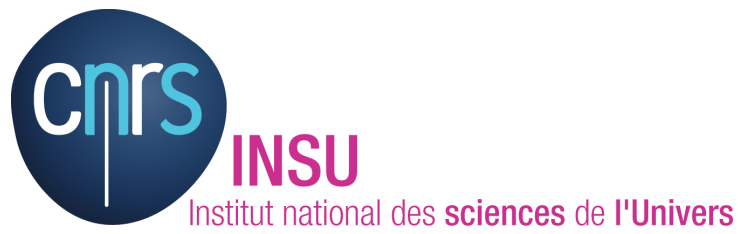

The publication of this article is financed by CNRS-INSU.

\section{References}

Baker, A. R., Jickells, T. D., Witt, M., and Linge K. L.: Trends in the solubility of iron, aluminium, manganese and phosphorus in aerosol collected over the Atlantic Ocean, Mar. Chem., 98, 4358, 2006.

Blain, S., Quéguiner, B., Armand, L., Belviso, S., Bombled, B., Bopp, L., Bowie, A. R., Brunet, C., Brussaard, C., Carlotti, F., Christaki, U., Corbière, A., Durand, I., Ebersbach, F., Fuda, J. L., Garcia, N., Gerringa, L., Griffiths, B., Guigue, C., Guillerm, C., Jacquet, S., Jeandel, C., Laan, P., Lefèvre, D., Lo Monaco, C., Malits, A., Mosseri, J., Obernesterer, I., Park, Y. H., Picheral, M., Pondaven, P., Remenyi, T., Sandroni, V., Sarthou, G., Savoye, N., Scoarnec, L., Souhaut, M., Thuiller, D., Timmermans, K., Trull, T., Uitz, J., van Beek, P., Veldhuis, M., Vincent, D., Viollier, E., Vong, L., and Wagener, T.: Effect of natural iron fertilization on carbon sequestration in the Southern Ocean, Nature, 446, 7139, 1070-1074, 2007.

Blain, S., Sarthou, G., and Laan, P.: Distribution of dissolved iron during the natural iron-fertilization experiment KEOPS (Kerguelen Plateau, Southern Ocean), Deep Sea Res. II, 55(5-7), 594 $605,2008$.

Bonnet, S. and Guieu C.: Dissolution of atmospheric iron in seawater, Geophys. Res. Lett., 31(3), L03303, doi:10.1029/2003GL018423, 2004.

Bowie, A. R., Sedwick, P. N., and Worsfold, P. J.: Analytical intercomparison between flow injection-chemiluminescence and flow injection-spectrophotometry for the determination of picomolar concentrations of iron in seawater, Limnol. Oceanogr. Methods, 2, 42-54, 2004.

Boyd, P. W., Watson, A. J., Law, C. S., Abraham, E. R., Trull, T., Murdoch, R., Bakker, D. C. E., Bowie, A., Buesseler, K. O., Chang, H., Charette, M., Croot, P., Downing, K., Frew, R., Gall, M., Hadfield, M., Hall, J., Harvey, M., Jameson, G., LaRoche, J., Liddicoat, M., Ling, R., Maldonado, M. T., McKay, R. M., Nodder, S., Pickmere, S., Pridmore, R., Rintoul, S., Safi, K., Sutton, P., Strzepek, R., Tanneberger, K., Turner, S., Waite, A., and Zeldis, J.: A mesoscale phytoplankton bloom in the polar Southern Ocean stimulated by iron fertilization, Nature, 407, 695-702, 2000.

Boyd, P. W., Law, C. S., Wong, C. S., Nojiri, Y., Tsuda, A., levasseur, M., Takeda, S., Rivkin, R., Harrison, P. J., Strzepek, R., Gower, J., McKay, R. M., Abraham, E., Arychuk, M., Barwell, C. J., Crawford, W., Crawford, D., Hale, M., Harada, K., Johnson, K., Kiyosawa, H., Kudo, I., Marchetti, A., Miller, W., Needoba, J., Nishioka, J., Ogawa, H., Page, J., Robert, M., Saito, H., Sastri, A., Sherry, N., Soutar, T., Sutherland, N., Taira, Y., Whitney, F., Wong, S. K. E., and Yoshimura, T.: The decline and fate of an iron-induced subarctic phytoplankton bloom, Nature, 428, 549-553, 2004.

Boyd, P. W., Law, C. S., Hutchins, D. A., Abraham, E. R., Croot, P. L., Ellwood, M., Frew, R. D., Hadfield, M., Hall, J., Handy, S., Hare, C. E., Higgins, J., Hill, P., Hunter, K. A., Leblanc, K., Maldonado, M. T., Mckay, R. M., Mioni, C., Oliver, M., Pickmere, S., Pinkerton, M., Safi, K., Sander, S., SanudoWilhelmy, S. A., Smith, M., Strzepek, R., Tavor-Sanchez, A., and Wilhelm S. W.: FeCycle: Attempting an iron biogeochemical budget from a mesoscale SF6 tracer experiment in unperturbed low iron waters, Global Biogeochem. Cy., 19, GB4S20, doi:10.1029/2005GB002494, 2005. 
Bruland, K. W. and Rue, E. L.: Analytical Methods for the Determination of Concentrations and Speciation of Iron, Biogeochemistry of Fe in Seawater, D.R. Turner and K.A. Hunter, SCOR/IUPAC series, J Wiley, Chapter 6, 255-290, 2001.

Buesseler, K. O., Andrews, J. E., Pike, S. M., and Charette, M. A.: The effects of iron fertilization on carbon sequestration in the Southern Ocean, Science, 304, 5669, 414-417, 2004.

Chase, Z., Johnson, K. S., Elrod, V. A., Plant, J. N., Fitzwater, S. E., Pickella, L., and Sakamoto, C. M.: Manganese and iron distributions off central California influenced by upwelling and shelf width, Mar. Chem., 95, 235-254, 2005.

Chen, M. and Wang, W.-X.: Bioavailability of natural colloidbound iron to marine plankton: Influences of colloidal size and aging, Limnol. Oceanogr., 46(8), 1956-1967, 2001.

Coale, K. H., Johnson, K. S., Chavez, F. P., Buesseler, K. O., Barber, R. T., Brzezinski, M. A., Cochlan, W. P., Millero, F. J., Falkowski, P. G., Bauer, J. E., Wanninkhof, R. H., Kudela, R. M., Altabet, M. A., Hales, B. E., Takahashi, T., Landry, M. R., Bidigare, R. R., Wang, X. J., Chase, Z., Strutton, P. G., Friederich, G. E., Gorbunov, M. Y., Lance, V. P., Hilting, A. K., Hiscock, M. R., Demarest, M., Hiscock, W. T., Sullivan, K. F., Tanner, S. J., Gordon, R. M., Hunter, C. N., Elrod, V. A., Fitzwater, S. E., Jones, J. L., Tozzi, S., Koblizek, M., Roberts, A. E., Herndon, J., Brewster, J., Ladizinski, N., Smith, G., Cooper, D., Timothy, D., Brown, S. L., Selph, K. E., Sheridan, C. C., Twining, B. S., and Johnson, Z. I.: Southern ocean iron enrichment experiment: Carbon cycling in high- and low-Si waters, Science, 304, 5669, 408-414, 2004.

Croot, P. L., Streu, P., and Baker, A. R.: Short residence time for iron in surface seawater impacted by atmospheric dry deposition from Saharan dust events, Geophys. Res. Lett, 31, L23S08, doi:10.1029/2004GL020153, 2004.

Cullen, J. T. and Sherrell, R. M.: Techniques for determination of trace metals in small samples of size-fractionated particulate matter: phytoplankton metals off central California, Mar. Chem., 67(3-4), 233-247, 1999.

Cullen, J. T., Bergquist, B. A., and Moffett, J. W.: Thermodynamic characterization of the partitioning of iron between soluble and colloidal species in the Atlantic Ocean, Mar. Chem., 98, 295303, 2006.

de Baar, H. J. W., de Jong, J. T. M., Nolting, R. F., Timmermans, K. R., van Leeuwe, M. A., Bathmann, U., van der Loeff, M. R., and Sildam, J.: Low dissolved $\mathrm{Fe}$ and the absence of diatom blooms in remote Pacific waters of the Southern Ocean, Mar. Chem., 66, 1-34, 1999.

de Baar, H. J. W. and de Jong, J. T. M.: Distributions, Sources and Sinks of Iron in Seawater, Biogeochemistry of Fe in Seawater, D. R. Turner and Hunter, K. A., Baltimore, SCOR-IUPAC series, J Wiley, Chapter 5, 123-253, 2001.

de Baar, H. J. W., Boyd, P. W., Coale, K. H., and Tsuda, A.: Synthesis of eight in situ iron fertilizations in high nutrient low chlorophyll waters confirms the control by wind mixed layer depth of phytoplankton blooms, J. Geophys. Res., 110, 700-724, 2005.

Elrod, V. A., Berelson, W. M., Coale, K. H., and Johnson, K. S.: The flux of iron from continental shelf sediments: A missing source for global budgets, Geophys. Res. Lett., 31, L12307, doi:10.1029/2004GL020216, 2004.

Fitzwater, S. E., Johnson, K. S., Elrod, V. A., Ryana, J. P., Colettia, L. J., Tanner, S. J., Gordon, R. M., and Chavez, F. P.: Iron, nu- trient and phytoplankton biomass relationships in upwelled waters of the California coastal system, Cont. Shelf Res., 23, 15231544, 2003.

Frew, R. D., Hutchins, D. A., Nodder, S., Sanudo-Wilhelmy, S., Tovar-Sanchez, A., Leblanc, K., Hare, C. E., and Boyd, P. W.: Particulate iron dynamics during FeCycle in subantarctic waters southeast of New Zealand, Global Biogeochem. Cy., 20, GB1S93, doi:10.1029/2005GB002558, 2006.

Gardner, W. D., Richardson, M. J., Carlson, C. A., Hansell, D., and Mishonov, A. V.: Determining true particulate organic carbon: bottles, pumps and methodologies, Deep Sea Res. II, 50(3-4), 655-674, doi:10.1016/S0967-0645(02)00589-1, 2003.

Jacquet, S. H. M., Dehairs, F., Savoye, N., Obernosterer, I., Christaki, U., Monnin, C., and Cardinal, C.: Mesopelagic organic carbon remineralization in the Kerguelen Plateau region tracked by biogenic particulate Ba, Deep Sea Res. II, 55(5-7), 868-879, 2008.

Jickells, T.: The inputs of dust derived elements to the Sargasso Sea: a synthesis, Mar. Chem., 68, 5-14, 1999.

Jickells, T. and Spokes, L. J.: Atmospheric iron inputs to the oceans. The biogeochemistry of Iron in seawater, edited by: Turner, D. R. and Hunter, K. A., Baltimore, SCOR-IUPAC series, J Wiley, Chapter 4, 85-121, 2001.

Jickells, T. D., An, Z. S., Andersen, K. K., Baker, A. R., Bergametti, G., Brooks, N., Cao, J. J., Boyd, P. W., Duce, R. A., Hunter, K. A., Kawahata, H., Kubilay, N., La Roche, J., Liss, P. S., Mahowald, N., Prospero, J. M., Ridgwell, A. J., Tegen, I., and Torres, R.: Global Iron Connections Between Desert Dust, Ocean Biogeochemistry, and Climate, Science, 308, 67-71, 2005.

Johnson, K. S., Chavez, F. P., Elrod, V. A., Fitzwater, S. E., Pinnington, J. T., Buck, K. R., and Walz, P. M.: The annual cycle of iron and the biological response in central California coastal waters, Geophys. Res. Lett., 28(7), 1247-1250, 2001.

Johnson, K. S., Boyle, E., Bruland, K., Coale, K., Measures, C., and Moffett, J.: Sampling and Analysis of Fe: The SAFE Iron Intercomparison Cruise, Eos Trans. AGU, 87, 36, Ocean Sci. Meet. Suppl., Abstract OS11N-02, 2006.

Johnson, K. S., Boyle, E., Bruland, K., Coale, K., Measures, C., and Moffett, J.: Developing Standards for Dissolved Iron in Seawater, Eos Trans. AGU, 88(11), 131-132, 2007.

Kuma, K., Katsumoto, A., Nishioka, J., and Matsunaga, K.: Sizefractionnated iron concentrations and Fe(III) hydroxide solubilities in various coastal waters, Estuarine, Coast. Shelf Sci., 47, 275-283, 1998.

Kutska, A. B., Carpenter, E. J., and Sanudo-Wilhelmy, S. A.: Iron and marine nitrogen fixation: progress and future directions, Res. Microbiol., 153, 255-262, 2002.

Lannuzel, D., Remenyi, T., Lam, P., Townsend, A., Ibisanmi, E., Butler, E., Wagener, T., Schoemann, V., and Bowie, A. R.,: Distribution of dissolved and particulate iron in the sub-Antarctic and Polar Frontal Southern Ocean (Australian sector), Deep Sea Res. II, accepted, 2010.

Löscher, B. M., de Baar, H. J. W., de Jong, J. T. M., Veth, C., and Dehairs, F.: The distribution of $\mathrm{Fe}$ in the Antarctic Circumpolar Current. Ecology and biogeochemistry of the Antarctic Circumpolar Current during austral spring: Southern Ocean JGOFS cruise ANT X/6 of R.V. Polarstern, Deep Sea Res. II, 44(1-2), 143-187, 1997.

Maldonado, M. T. and Price, N. M.: Reduction and transport of 
organically bound iron by Thalassiosira oceanica (Bacillariophyceae), J. Phycol, 37(2), 298-309, 2001.

Maraldi, C., Mongin, M., Coleman, R., and Testut, L.: The influence of lateral mixing on a phytoplankton bloom: Distribution in the Kerguelen Plateau region, Deep Sea Res. I., 56(6), 963-973, 2009.

Mongin, M., Molina, E., and Trull, T. W.: Seasonality and scale of the Kerguelen plateau phytoplankton bloom: A remote sensing and modeling analysis of the influence of natural iron fertilization in the Southern Ocean, Deep Sea Res. II, 55, 880-892, 2008.

Morel, F. M. M., Kustka, A. B., and Shaked, Y.: The role of unchelated $\mathrm{Fe}$ in the iron nutrition of phytoplankton, Limnol. Oceanogr., 53(1), 400-404, 2008.

Obata, H., Karatani, H., and Nakayama, E.: Automated determination of iron in seawater by chelating resin concentration and chemiluminescence, Anal. Chem., 65, 1524-1528, 1993.

Park, Y.-H., Roquet, F., Durand, I., and Fuda, J. L.: Large-scale circulation over and around the Northern Kerguelen Plateau, Deep Sea Res. II, 55(5-7), 566-581, 2008a.

Park, Y.-H., Fuda, J.-L., Durand, I., and Naveira Garabato, A. C.: Internal tides and vertical mixing over the Kerguelen Plateau, Deep Sea Res. II, 55(5-7), 582-593, 2008b.

Planquette, H., Statham, P. J., Fones; G. R., Charette, M. A., Moore, C. M., Salter, I., Nedelec, F. H., Taylor, S. L., French, M., Baker, A. R., Mahowald, N., and Jickells, T. D.: Dissolved iron in the vicinity of the Crozet Islands, Southern Ocean, Deep Sea Res. II, 54, 1999-2019, 2007.

Pollard, R. T., Salter, I., Sander, S., Lucas, M. I., Moore, C. M., Mills, R. A., Statham, P. J., Allen, J. T., Baker, A. R., Bakker, D. C. E., Charette, M. A., Fielding, S., Fones, G. R., French, M., Hickman, A. E., Holland, R. J., Hughes, J. A., Jickells, T. D., Lampitt, R. S., Morris, P. J., Nedelec, F. H., Nielsdottir, M., Planquette, H., Popova, E. E., Poulton, A. J., Read, J. F., Seeyave, S., Smith, T., Stinchcombe, M., Taylor, S. L., Thomalla, S., Venables, H. J., Williamson, R., and Zubkov, M.: Southern Ocean deep-water carbon export enhanced by natural iron fertilization, Nature, 457, 577-581, 2009.

Powell, R. T., King, D. W., and Landing, W. M: Iron distributions in the surface waters of the south Atlantic, Mar. Chem., 50(1-4), 13-20, 1995.

Rueter, J. G. and Ades, D. R.: The role of iron nutrition in photosynthesis and nitrogen assimilation in Scenedesmus quadeicauda (Chlorophyceae), J. Physicol., 23, 452-457, 1987.

Sarthou, G., Jeandel, C., Brisset, L., Amouroux, D., and Donard, O. F. X.: $\mathrm{Fe}$ and $\mathrm{H}_{2} \mathrm{O}_{2}$ distributions in the upper 250 meters of the water column in the Indian sector of the Southern Ocean, Earth Planet. Sci. Lett., 147, 83-92, 1997.
Sarthou, G. and Jeandel, C.: Seasonal variations of iron concentrations in the Ligurian Sea and iron budget in the Western Mediterranean Sea, Mar. Chem., 74(2-3), 115-129, 2001.

Sarthou, G., Baker, A. R., Blain, S., Achterberg, E. P., Boye, M., Bowie, A. R., Croot, P. L., Laan, P., de Baar, H. J. W., Jickells, T. D., and Worsfold, P. J.: Atmospheric iron deposition and sea-surface dissolved iron concentrations in the eastern Atlantic Ocean, Deep Sea Res. I, 50(10-11), 1339-1352, 2003.

Sarthou, G., Baker, A. R., Kramer, J., Laan, P., Laës, A., Ussher, S., Achterberg, E. P., de Baar, H. J. W., Timmermans, K. R., and Blain, S.: Influence of atmospheric inputs on the iron distribution in the subtropical North-East Atlantic Ocean, Mar. Chem., 104, 186-202, 2007.

Sarthou, G., Vincent, D., Christaki, U., Obernesterer, I., Timmermans, K. R., and Brussaard, C. P. D.: The fate of biogenic iron during a phytoplankton bloom induced by natural fertilization: Impact of copepod grazing, Deep Sea Res. II, 55(5-7), 734-751, 2008.

Schlitzer, R.: Ocean Data View, online available at: http://odv.awi. de, 2007.

Sedwick, P. N., Edwards, P. R., Mackey, D. J., Griffiths, F. B., and Parslow, J. S.: Iron and manganese in surface waters of the Australian subantarctic region, Deep-Sea Res. I, 44, 1239-1253, 1997.

Sedwick, P. N., Bowie, A. R., and Trull, T. W.: Dissolved iron in the Australian sector of the Southern ocean (CLIVAR SR3 section): Meridional and seasonal trends, Deep Sea Res. I, 55, 911-925, 2008.

Sunda, W. G.: Trace metal interactions with marine phytoplankton, Biol. Oceanogr., 6, 411-442, 1989.

Townsend, A. T.: The accurate determination of the first row transition metals in water, urine, plant, tissue and rock samples by sector field ICP-MS, J. Anal. Atom. Spec., 15, 307-314, 2000.

van Beek, P., Bourquin, M., Reyss J.-L., Souhaut, M., Charrette, M. A., and Jeandel, C.: Radium isotopes to investigate the water mass pathways on the Kerguelen Plateau (Southern Ocean), Deep Sea Res. II, 55(5-7), 622-637, 2008.

Wagener, T., Guieu, C., Losno, R., Bonnet, S., and Mahowald, N.: Revisiting atmospheric dust export to the Southern Hemisphere ocean: Biogeochemical implications, Global Biogeochem. Cy., 22, GB2006, doi:10.1029/2007GB002984, 2008.

Wu, J., Boyle, E., Sunda, W., and Wen, L.-S.: Soluble and colloidal iron in the oligotrophic North Atlantic and North Pacific, Science, 293, 847-849, 2001.

Zhang, Y., Lacan, F., and Jeandel, C.: Dissolved rare earth elements tracing lithogenic inputs over the Kerguelen Plateau (Southern Ocean), Deep Sea Res. II, 55(5-7), 638-652, 2008. 